\title{
Improved Learning Outcomes of Natural Science Lesson Grade V Assisted Cooperative Learnng Models
}

\author{
Faiqoh \\ SD Negeri Kreman 01 \\ Faiqohaja@gmail.com
}

\section{Article History}

accepted $14 / 11 / 2020$

approved $21 / 11 / 2020$

published 26/11/2020

\begin{abstract}
The purpose of this research was to improve student learning outcomes in science grade $V$ elementary schools with cooperative learning model The research conducted was a Classroom Action Research (PTK) with three cycle, with each cycle consisting of one meeting. The stages of each cycle are planning, implementing, observing and reflecting. In the first cycle the student who completed were $45 \%$. In the second cycle students who completed were $70 \%$. In the third cycle students who completed were $95 \%$. There result indicate that the cooperative learning model can improve student learning outcomes, especially grade $V$ science on human circulatory System highlights at SD Negeri Kreman 01.

Keywords: Learning outcomes, Cooperative Learning, Science
\end{abstract}

\begin{abstract}
Abstrak
Tujuan dari penelitian ini adalah untuk meningkatkan hasil belajar peserta didik pada Mapel IPA di sekolah dasar kelas $V$ dengan model pembelajaran cooperative learning. Penelitian yang dilakukan adalah Penelitian Tindakan Kelas (PTK) sebanyak tiga siklus dengan setiap siklusnya terdiri dari satu pertemuan. Tahapan setiap siklusnya adalah perencanaan, pelaksanaan, observasi dan refleksi, Pada siklus I peserta didik yang tuntas $45 \%$, Pada siklus II peserta didik yang tuntas sebesar $70 \%$, Pada siklus III peserta didik yang tuntas sebesar $95 \%$. Hasil ini menunjukan bahwa model pembelajaran cooperative learning dapat meningkatkan hasil belajar peserta didik khususnya mapel IPA materi sistem peredaran darah manusia kelas $V$ di SD Negeri Kreman 01.

Kata kunci: Hasil belajar, Coopratif Learning, IPA
\end{abstract}

Social, Humanities, and Education Studies (SHEs): Conference Series https://jurnal.uns.ac.id/shes 


\section{PENDAHULUAN}

Pendidikan sebagai salah satu proses dalam hidup manusia bertujuan untuk memperoleh pengetahuan dan keterampilan yang diperlukan dalam peranannya di masyarakat. Pendidikan adalah salah satu aspek penting dalam kehidupan setiap manusia. Manusia yang terdidik dapat menjadi manusia yang beradab, bersopan santun dan berbudaya.

Namun demikian, terkadang tujuan mulia ini belum dapat tercapai sesuai dengan harapan. Hal ini lebih banyak diakibatkan karena proses mendidik melalui proses belajar mengajar masih didominasi dengan pendekatan satu arah, dimana guru disebut-sebut sebagai pusat informasi, guru dianggap sebagai pusat kebenaran. Akibatnya siswa dikondisikan untuk harus mendengar dan patuh sepenuhnya apa kata guru. Akibat dari pola pembelajaran seperti ini, motivasi belajar dan hasil belajar siswa menjadi rendah, karena siswa dikondisikan menjadi pasif dan hanya menjadi pendengar. Guru menjadi satu-satunya sumber informasi dan pengetahuan bagi siswa.

Guru yang cakap dan professional adalah guru yang terampil dalam memilih metode, media dan menetapkan strategi yang tepat dalam pembelajaran. Dalam proses pembelajaran IPA, siswa memperoleh latihan baik secara eksplisit maupun implisit tentang cara berfikir kreatif, terutama dalam memecahkan masalah-masalah. Sehingga mempunyai pandangan yang luas serta memiliki sikap menghargai kegunaan IPA, sikap kritis, objektif, terbuka, kreatif, dan inovatif.

Penggunaan model pembelajaran harus sesuai dengan materi yang disampaikan, jika tidak sesuai maka tujuan pembelajaran yang diiginkan tidak akan tercapai. Hasil belajar IPA juga akan rendah karena peserta didik tidak memahami materi pelajaran yang disampaikan. Kasus rendahnya pemahaman peserta didik mengenai materi IPA masih banyak terjadi di SD di sekitar kita, seperti halnya di SD Kreman 01 Warureja. Hasil belajar IPA pada materi sistem peredaran darah dari peserta didik kelas $\mathrm{V}$ masih rendah, hal ini dapat dilihat dari hasil evaluasi dimana hanya terdapat $25 \%$ peserta didik yang sudah dinyatakan tuntas dengan Kriteria Ketuntasan Minimum (KKM) sebesar 70. Ketuntasan belajar klasikal belum tercapai, yaitu sebesar $75 \%$ peserta didik memperoleh nilai di atas KKM.

Hal ini tidak seperti yang diharapkan yakni siswa jarang diberikan kesempatan untuk bertanya, guru yang terus-menerus mendominasi pembelajaran dengan memberikan ceramah kepada siswa, sehingga saat dilakukan diskusi dan siswa diberikan kesempatan untuk mengemukakan pendapat, siswa menjadi tidak berani untuk menyampaikan pendapatnya, sebab siswa telah terkondisi untuk menjadi pasif dan bukan aktif dalam pembelajaran IPA. Akibatnya, siswa tidak terlatih memahami isi pelajaran IPA dan menjadi mudah melupakan materi pelajaran tersebut.

Melihat kondisi demikian, penelitian ini dilakukan dalam maksud untuk melihat apakah dengan menggunakan model pembelajaran yang berbeda, dapat memiliki pengaruh khususnya dalam membangkitkan motivasi belajar dan hasil belajar siswa. Melalui penelitian ini, penulis menawarkan model pembelajaran cooperative learning. model pembelajaran cooperative learning menurut Nurhadi (2004) adalah pendekatan pembelajaran yang berfokus pada penggunaan kelompok kecil siswa untuk bekerja sama dalam memaksimalkan kondisi belajar untuk mencapai tujuan belajar.

Nur (2005) menyatakan bahwa model pembelajaran cooperative learning dapat memotivasi seluruh siswa,memanfaatkan seluruh energi sosial siswa, saling mengambil tanggung jawab. Berdasarkan pendapat tersebut diatas, model pembelajaran cooperative learning dapat menimbulkan rasa gotong royong yang tinggi, tidak membeda-bedakan antar ras dan intelegensi, melatih siswa berpikir aktif dan kreatif. Disamping itu juga pelaksanaan proses pembelajaran dalam suasana komunikasi dua arah, diharapkan siswa juga dapat melakukannya dalam suasana komunikasi multi arah. Dalam proses pembelajaran seperti ini hubungan tidak hanya 
terjadi antara seorang guru dengan siswa dan sebaliknya, tetapi juga antara siswasiswa lainnya (Muhibbin Syah, 2005)

Seperti dipaparkan oleh Nurhadi (2004) bahwa pembelajaran cooperative learning merupakan model pembelajaran dimana siswa di dalam kelas dibagi ke dalam beberapa kelompok atau tim yang masing-masing terdiri atas 4 sampai 5 orang anggota kelompok yang memiliki latar belakang kelompok yang heterogen, baik jenis kelamin, ras etnik, maupun kemampuan intelektual (tinggi, rendah, sedang). Tiap anggota tim menggunakan lembar kerja akademik dan kemudian saling membantu untuk menguasai bahan ajar melalui tanya jawab atau diskusi antar sesama anggota tim. Langkah-langkah yang harus diperhatikan dalam melaksanakan model pembelajaran cooperative learning adalah menyampaikan tujuan pembelajaran dan memotivasi siswa menyampaikan informasi, mengorganisasikan siswa ke dalam beberapa kelompok belajar, membimbing siswa untuk belajar kelompok, melakukan evaluasi, dan memberikan penghargaan (Alipandie, Imansyah)

Joko Susilo (2009) mengatakan bahwa belajar adalah modifikasi atau memperteguh kelakuan melalui pengalaman. Dalam pengertian ini, belajar adalah merupakan suatu proses, satu kegiatan dan bukan suatu hasil atau tujuan. Belajar bukan hanya mengingat, akan tetapi lebih luas dari pada itu yakni mengalami. Hasil belajar bukan penguasaan dan latihan, melainkan perubahan kelakuan Menurut Omar Hamalik (2002), belajar adalah perubahan tingkah laku yang relatif mantap berkat latihan dan pengalaman

Sudjana (2002) menjelaskan bahwa hasil belajar sebagai kemampuan yang dimiliki siswa setelah ia menerima pengalaman belajar. Masih menurut Sudjana (2002) mengemukakan bahwa hasil belajar adalah upaya atau tindakan untuk mengetahui sejauh mana tujuan yang telah ditetapkan itu tercapai atau tidak.

Berdasarkan pengertian di atas, maka dapat disimpulkan bahwa hasil belajar adalah kemampuan yang dimiliki siswa karena memiliki pengalaman belajar, dimana hasilnya dapat dilihat pada perubahan pada ranah kognitif, afektif dan psikomotorik. Meskipun demikian, dalam penelitian ini hasil belajar lebih dimaksudkan sebagai kemampuan yang dimiliki siswa karena telah memiliki pengalaman belajar pada mata pelajaran IPA, dimana perubahannya lebih dibatasi hanya pada ranah kognitif

\section{METODE}

Penelitian ini adalah Penelitian Tindakan Kelas (Classroom Action Research) dengan menerapkan model pembelajaran cooperative learning. Menurut Kurt Lewin dalam kunandar (2011) penelitian tindakan kelas ini terdiri dari empat tahapan dasar yaitu perencanaan (planning), pelaksanaan (acting), pengamatan (observing) dan refleksi (reflecting). Analisis penelitian ini adalah analisis deskriptif kuantitatif kualitatif dimana dalam penelitian ini selain penyajian hasil berupa data maupun angka peneliti juga menentukan bagaimana cara pengolahan hasil penelitian yaitu dengan membuat analisisnya dengan menerapkan model penelitian pembelajaran cooperative learning. Penelitian ini dilaksanakan pada peserta didik kelas V SD Negeri Kreman 01 Tahun pelajaran 2020/2021 selama tiga siklus, siklus I dilaksanakan pada tanggal 2 November 2020, siklus II dilaksanakan pada tanggal 9 November 2020, siklus III dilaksanakan pada tanggal 20 November 2020. Teknik pengumpulan data yang dilakukan yaitu dengan observasi dan tes, baik pre tes maupun post tes. Observasi meliputi observasi sikap maupun ketrampilan dari peserta didik. Untuk hasil belajar menggunakan tes evaluasi berupa soal tes evaluasi pilihan ganda.

\section{HASIL DAN PEMBAHASAN}

Berdasarkan hasil analisis hasil penelitian yang telas diuraikan maka pembahasan pada penelitian ini adalah sebagai berikut : 


\section{Penerapan Model Cooprative Learning}

Hasil penelitian menunjukan peningkatan penerapan model pembelajaran cooperative learning yang dilakukan oleh guru, terlihat pada table berikut :

Tabel 1. Peningkatan Penerapan Model Cooperative Learning

\begin{tabular}{lccc}
\hline \multicolumn{1}{c}{ Langkah } & Siklus I & Siklus II & Siklus III \\
\hline Menyampaikan tujuan pembelajaran peserta didik & 2 & 3 & 4 \\
\hline Menyajikan informasi kepada peserta didik & 2 & 3 & 3 \\
\hline $\begin{array}{l}\text { Mengorganisasikan peserta didik ke dalam kelompok } \\
\text { kelompok belajar }\end{array}$ & 4 & 4 & 4 \\
\hline Membimbing kelompok belajar & 3 & 3 & 4 \\
\hline Mengevaluasi hasil belajar & 3 & 3 & 3 \\
\hline $\begin{array}{l}\text { Memberi penghargaan hasil belajar individual dan } \\
\text { kelompok }\end{array}$ & 4 & 4 & 4 \\
\hline Rata - rata & 3.0 & 3.3 & 3.7 \\
\hline Prosentase ketuntasan & 75 & 83 & 92 \\
\hline
\end{tabular}

Penerapan model cooperative learning dalam pembelajaran IPA meliputi langkah-langkah: (1) Guru menyampaikan semua tujuan pembelajaran yang ingin dicapai pada pembelajaran dan memotivasi peserta didik untuk belajar, (2) Guru menyajikan informasi kepada siswa dengan jalan demonstrasi atau lewat bacaanbacaan, (3) Mengorganisasikan siswa kedalam kelompok-kelompok belajar dan membantu setiap kelmpok belajar agar melakukan transisi secara efesiensi, (4) Guru membimbing kelompok-kelompok belajar pada saat mereka mengerjakan tugas mereka, (5) Guru mengevaluasi hasil belajar tentang materi yang dipelajari atau masing-masing kelompok mempresentasikan hasil kerjanya, (6) Guru mencari caracara untk menghargai baik upaya maupun hasil belajar individu.

Langkah-langkah model pembelajaran cooperative learning dilaksanakan dalam penelitian ini sejalan dengan penelitian yang dilakukan oleh Dinayati (2016) yang melakukan penelitian dengan topik peningkatan hasil belajar siswa melalui model cooperative learning tipe Student Teams Achievement Divisions (STAD) pada mata pelajaran IPA dikelas V SDN 20 Tolitoli.

2. Hasil Belajar pada materi system peredaran darah pada manusia

Hasil penelitian menunjukan peningkatan hasil belajar pada materi sistem peredaran darah pada manusia, terlihat pada tabel berikut :

Tabel 2. Peningkatan Hasil Belajar

\begin{tabular}{cccccccc}
\hline \multirow{2}{*}{ Nilai } & \multicolumn{2}{c}{ Siklus I } & \multicolumn{2}{c}{ Siklus II } & \multicolumn{2}{c}{ Siklus III } \\
\cline { 2 - 8 } & $\mathrm{F}$ & $\%$ & $\mathrm{~F}$ & $\%$ & $\mathrm{~F}$ & $\%$ \\
\hline 100 & - & 0 & 1 & 5 & 6 & 30 \\
\hline 90 & - & 0 & 3 & 15 & 6 & 30 \\
\hline 80 & 3 & 15 & 7 & 35 & 5 & 25 \\
\hline 70 & 6 & 30 & 2 & 10 & 2 & 10 \\
\hline 60 & 4 & 20 & 5 & 25 & - & - \\
\hline 50 & 4 & 20 & 2 & 10 & 1 & 5 \\
\hline 40 & 2 & 10 & - & - & - & - \\
\hline 30 & 1 & 5 & - & - & - & - \\
\hline Jumlah & 20 & 100 & 20 & 100 & 20 & 100 \\
\hline Rata-rata & 60.5 & - & 74.5 & - & 86.5 & - \\
\hline Tuntas & 9 & 45 & 14 & 70 & 19 & 95
\end{tabular}

Penilaian hasil belajar IPA peserta didik pada materi sistem peredaran darah manusia diukur dengan menggunkan teknik tes dengan instrument lembar soal 
evaluasi. Teknik pengumpulan data hasil belajar peserta didik ditetapkan disetiap pertemuan setelah dilakukan proses pembelajaran. Aspek yang diukur yaitu kognitif atau pengetahuan yang terdiri dari mengingat (C1), memahami (C2), mengaplikasi (C3), dan menganalisis (C4) yang diukur berdasarkan hasil evaluasi setelah mengikuti pembelajaran dengan penggunaan model pembelajaran cooperative learning pada materi sistem peredaran darah manusia.

Penggunaan model pembelajaran cooperative learning dalam pembelajaran IPA dapat meningkatkan hasil belajar peserta didik di kelas V SD Negeri Kreman 01 Tegal secara signifikan. Pada hasil penilaian pra siklus terdapat 15 dari 20 peserta didik yang belum mencapai KKM dengan persentase ketentutasan hasil belajar hanya $25 \%$, setelah dilakukan tindakan persentase ketuntasan hasil belajar pada siklus I meningkat menjadi $45 \%$ dan pertemuan siklus II menjadi $70 \%$, pada siklus II terjadi peningkatan kembali pada 95\%. Berdasarkan hasil diatas, rata-rata ketuntasan hasil belajar pada siklus I sebesar 60.5, siklus II 74.5 dan siklus III sebesar 86.5.

Pada siklus I belum mencapai indikator kinerja penelitian yang ditetapkan yaitu ketuntasan belajar hanya sebesar $45 \%$. Hasil siklus ke II mengalami peningkatan namun masih belum mencapai indikator kinerja penelitian yang ditetapkan. Pada siklus III, ketuntasan hasil belajar IPA peserta didik telah mencapai 95\% dengan KKM 70 sehingga pelaksanaan tindakan dapat dihentikan.

Berdasarkan analisis hasil belajar peserta didik setelah pelaksanaan tindakan, dapat diambil kesimpulan bahwa penggunaan model pembelajaran cooperative learning dapat meningkatkan hasil belajar IPA pada materi sistem peredaran darah manusia, hal ini sesuai dengan hasil penelitian yang dilakukan oleh Dinayanti yang membuktikan bahwa model pembelajaran cooperative learning dapat meningkatkan hasil belajar IPA di kelas V SDN 20 Tolitoli secara signifikan, hasil penelitian ini juga memperkuat pendapat Supriyono (2009) bahwa penggunaan metode cooperative learning berpengaruh baik pada proses pembelajaran dan hasil belajar IPA meningkat secara signifikan.

\section{SIMPULAN}

Berdasarkan hasil penelitian dan uraian pembahasan maka dapat diambil kesimpulan sebagai berikut :

Penggunaan model pembelajaran cooperatif learning untuk meningkatkan hasil belajar siswa kelas $\mathrm{V}$ pada mapel IPA materi sistem peredaran darah manusia dilaksanakan dengan langkah-langkah: (1) Menyampaikan tujuan dan memotivasi siswa, (2) Menyajikan informasi, (3) Mengorganisasikan siswa kedalam kelompokkelompok belajar, (4) Membimbing kelompok bekerja dan belajar, (5) Evaluasi, dan (6) Memberikan penghargaan.

Penggunaan model pembelajaran cooperative learning dapat meningkatkan hasil belajar peserta didik kelas V pada mapel IPA materi sistem peredaran darah manusia yang dibuktikan dengan rata-rata ketuntasan hasil belajar peserta didik pasa siklus I sebesar 60.5, siklus II meningkat menjadi 74.5 dan meningkat menjadi 86.5 pada siklus III.

Peningkatan yang terjadi karena adanya kesan bahwa pembelajaran cooperative learning dapat merangsang siswa lebih bergairah dalam belajar. Sistem pengajaran pada pembelajaran ini memberi kesempatan kepada peserat didik untuk bekerja sama dan saling membantu satu sama lain dalam mempelajari materi pembelajaran. 


\section{DAFTAR PUSTAKA}

Alipandie, I.(1984). Didaktif Metodik Pendidikan Umum. Surabaya: Usaha Nasional.

Dinayati.(2011).Peningkatan Hasil Belajar Slswa Melalui Model Cooperative LearningTipe STAD pada Mata Pelajaran IIPA di Kelas V SDN Tolitoli.Jurnal Kreatif Tadulako Online PGSD FIP UNIVERSITAS Tadulako.

Joko, S.M. (2009). Sukses dengan Gaya Belajar. Yogyakarta: Pinus.

Muhibbin, S.(2008). Psikologi Pendidikan. Bandung: PT Remaja Rosdakarya.

Nur, M.(2005). Pembelajaran Kooperatif. Surabaya: UNESA Press.

Nurhadi. (2004).Pembelajaran Konstektual (Contextual Teaching \& Learning (CTL)) dan Penerapannya dalam KBK. Malang: Universitas Negeri Malang.

Nurhadi. (2004). Penerapan Pembelajaran Kooperatif Tipe STAD untuk Meningkatkan Kualitas Proses Belajar Mengajar Biologi SMA. Surabaya: PPS IKIP Surabaya.

Omar, H.(2002). Perubahan tingkah laku yang relatif mantap berkat latihan dan pengalaman. Bandung: Nusa Media.

Sudjana, N. (2002). Dasar-Dasar Proses Belajar Mengajar. Bandung: Sinar Baru. 